\title{
Selenoesters and selenoanhydrides as novel multidrug resistance reversing agents: a confirmation study in a colon cancer MDR cell line
}

\author{
Márió Gajdács ${ }^{\mathrm{a}}$, Gabriella Spengler $^{\mathrm{a}}$, Carmen Sanmartín ${ }^{\mathrm{b}}$, Małgorzata Anna Marćc ${ }^{\text {, Jadwiga Handzlik }}$ \\ and Enrique Domínguez-Álvarez ${ }^{\mathrm{b}, \mathrm{c}^{*}}$ \\ ${ }^{a}$ Department of Medical Microbiology and Immunobiology, Faculty of Medicine, University of Szeged, Dóm tér 10, 6720 Szeged, Hungary \\ ${ }^{b}$ Department of Organic and Pharmaceutical Chemistry. School of Pharmacy, University of Navarra, Irunlarrea 1, 31010 Pamplona, Spain. \\ ${ }^{c}$ Department of Technology and Biotechnology of Drugs. Jagiellonian University Medical College. Medyczna 9, 30-688 Kraków, Poland.
}

ARTICLE INFO

Article history:

Received

Revised

Accepted

Available online

\section{Keywords:}

Selenium

Multidrug resistance (MDR)

Selenoesters

Cancer

Apoptosis

MDR efflux pumps

$\underline{\text { ABCB1 efflux pump (P-glycoprotein) }}$

Different organic and inorganic selenocompounds have been reported as anticancer agents ${ }^{1-2}$, and many of them have interesting applications in human health ${ }^{3}$. Sodium selenite ${ }^{4-7}$, sodium selenide ${ }^{8}$ and elemental Se-nanoparticles ${ }^{9-11}$ can be cited as examples of inorganic selenium-containing compounds with anticancer and/or apoptotic and/or antibacterial activity. Alternatively, among the active organic selenium derivatives, methylseleninic acid ${ }^{12-14}$, selenocyanates ${ }^{15-17}$, selenoureas ${ }^{18,19}$ and selenoesters $^{20-21}$ can be highlighted. The reported mechanisms of action for these compounds vary greatly: reduction of oxidative stress $^{22}$, induction of mutations ${ }^{23}$, angiogenesis inhibition ${ }^{16,24}$, apoptosis induction ${ }^{25}$ and reversal of multidrug resistance $(\mathrm{MDR})^{25}$. Interestingly, selenium and Se-containing compounds are like a double-edged sword ${ }^{26}$ : they can exert an antioxidant action that prevents cancer in normal cells ${ }^{1-3,22,26}$, whereas they can act in cancer cells as pro-oxidants that generate reactive oxygen species (ROS). These Se-induced ROS can then trigger apoptotic processes ${ }^{25,26}$ and can induce mutations in DNA, as well as DNA breaks ${ }^{23,26}$.

The multidrug resistance of cancers and bacterial infections is an increasing and troublesome problem nowadays, due to the appearance of resistant cancers and resistant bacterial strains ${ }^{27-28}$. It has been observed that one of the most common mechanisms of cancer MDR is the over-expression of the efflux pumps ${ }^{29}$, which are membrane proteins that can recognise and extrude out of the cells toxic agents such as the anticancer drugs ${ }^{29,30}$. In this context, different studies ${ }^{6,7,14-16,31-33}$ pointed out that selenocompounds can enhance the activity of the drugs used in cancer chemotherapy in a synergic way if they are applied together. Some examples of studies that have shown this synergistic enhancement of the chemotherapy drugs action are: (i) sodium selenite potentiates the cytotoxicity of imatinib in HCT116 colorectal cancer cells ${ }^{6}$; (ii) sodium selenite enhances the cytotoxicity of cisplatin in MCF-7 breast carcinoma cells ${ }^{7}$; (iii) the cytotoxicity of paclitaxel is augmented in presence of methylseleninic acid in MDA-MB-231 breast adenocarcinoma cells ${ }^{14}$; (iv) the combined treatment of mice with diphenylmethyl selenocyanate and cisplatin decreases the size of induced tumours ${ }^{15}$; (v) a complex organoselenocyanate inhibited the angiogenesis and enhanced the therapeutic efficacy of cyclophosphamide in tumour bearing Swiss albino mice ${ }^{16}$; (vi) selenocystine can potentiate the capacity of auronafin to induce apoptosis in A549 lung cancer cell line ${ }^{31}$, (vii) selenocystine also enhances the therapeutic effect of doxorubicin in liver carcinoma HepG2 cell line ${ }^{32}$; and (viii) Se-methylselenocysteine increases the antitumour activity of different chemotherapeutic agents in vivo (cisplatin, cyclophosphamide, oxaliplatin and irinotecan) in mice $^{33}$.

Taking in mind the aforesaid antecedents, and seeking to determine the influence of selenocompounds on multidrug resistance, we evaluated the capacity of a cyclic selenoanhydride and ten selenoesters ${ }^{20,21}$ to inhibit a MDR efflux pump such as the 
ABCB1 (ATP Binding Cassette Subfamily B Member 1) protein in MDR mouse T-lymphoma cells as shown previously ${ }^{25}$; as well as their capacity to trigger apoptotic events in these mouse Tlymphoma cells ${ }^{25}$. Results showed a noteworthy and promising activity, as the four most active compounds $(\mathbf{1}, \mathbf{9 - 1 1}$, Figure 1) exerted a (1.7-3.6)-fold stronger efflux pump inhibitory activity than the reference verapamil at concentration 10 -fold lower. In addition, those four most active selenium derivatives triggered apoptotic events in more than the $80 \%$ of the gated cells ${ }^{25}$.

Herein we have evaluated these selenocarbonyl derivatives 1-11 (Table 1) in a human MDR cell line of colon adenocarcinoma: the Colo 320/MDR-LRP cell line resistant to doxorubicin over-expressing ABCB1 (MDR1)-LRP ${ }^{27,34}$. The aim of our study is to compare the MDR reversing and efflux pump inhibiting properties of selenocompounds 1-11 in human cancer cell lines with the previous results in mouse cells ${ }^{25}$, as well as to evaluate their cytotoxicity in normal cells to determine their selectivity. For comparison, four additional compounds have been chosen as references to estimate the role of the presence of a selenium atom (Table 1). On one hand, the phthalic anhydride (12) has been selected as the oxygen isoster of the selenoanhydride $\mathbf{1}$. On the other hand, three inorganic compounds that represent different chalcogen cyanates have been evaluated, as follows: potassium cyanate (KOCN, 13), ammonium thiocyanate $\left(\mathrm{NH}_{4} \mathrm{SCN}, 14\right)$ and potassium selenocyanate $(\mathrm{KSeCN}, \mathbf{1 5})$

Table 1. Structure of the selenocarbonyl-containing compounds evaluated as multidrug resistance (MDR) reversing agents.

\section{Group A}

Selenoanhydride<smiles>O=C1[Se]C(=O)c2ccccc21</smiles>

1

\section{Group B}

Selenoesters<smiles>[R]C[Se]C(=O)c1cccc([R])c1</smiles>

2-11
Reference compounds
Phthalic anhydride

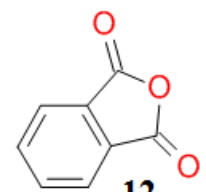

Chalcogen cyanates

13 - KOCN

$14-\mathrm{NH}_{4} \mathrm{SCN}$

$15-\mathrm{KSeCN}$

\begin{tabular}{cccccc}
\hline Cpd & Group & $\mathbf{n}$ & $\mathbf{X}$ & $\mathbf{R}^{\mathbf{1}}$ & $\mathbf{R}^{\mathbf{2}}$ \\
\hline $\mathbf{1}$ & $\mathbf{A}$ & - & - & - & - \\
$\mathbf{2}$ & $\mathbf{B}$ & 0 & $\mathrm{~S}$ & $5-\mathrm{COSeCH}_{3}$ & $-\mathrm{H}$ \\
$\mathbf{3}$ & $\mathbf{B}$ & 1 & $\mathrm{~N}$ & $6-\mathrm{COSeCH}_{3}$ & $-\mathrm{H}$ \\
$\mathbf{4}$ & $\mathbf{B}$ & 1 & $\mathrm{C}$ & $3-\mathrm{COSeCH}_{3}$ & $-\mathrm{H}$ \\
$\mathbf{5}$ & $\mathbf{B}$ & 1 & $\mathrm{C}$ & $4-\mathrm{COSeCH}_{3}$ & $-\mathrm{H}$ \\
$\mathbf{6}$ & $\mathbf{B}$ & 1 & $\mathrm{C}$ & $-\mathrm{H}$ & $-\mathrm{CONH}_{2}$ \\
$\mathbf{7}$ & $\mathbf{B}$ & 1 & $\mathrm{C}$ & $4-\mathrm{Cl}$ & $-\mathrm{COOCH}_{3}$ \\
$\mathbf{8}$ & $\mathbf{B}$ & 1 & $\mathrm{C}$ & $-\mathrm{H}$ & $-\mathrm{COOPh}^{2}$ \\
$\mathbf{9}$ & $\mathbf{B}$ & 1 & $\mathrm{C}$ & $4-\mathrm{Cl}$ & $-\mathrm{COCH}_{3}$ \\
$\mathbf{1 0}$ & $\mathbf{B}$ & 1 & $\mathrm{C}$ & $4-\mathrm{Cl}$ & $-\mathrm{COC}\left(\mathrm{CH}_{3}\right)_{3}$ \\
$\mathbf{1 1}$ & $\mathbf{B}$ & 1 & $\mathrm{C}$ & $3,5-\mathrm{diOCH}$ & $-\mathrm{COC}\left(\mathrm{CH}_{3}\right)_{3}$ \\
\hline
\end{tabular}

Cpd: Compound.
In this study we evaluate a series of the selenocompounds previously reported ${ }^{20,21}$ that showed activity ${ }^{25}$ as novel efflux pump inhibitors in parental L5178Y mouse T-lymphoma cells and in its MDR subline that expresses the ABCB1 protein after being transfected with the human $A B C B 1$ gene ${ }^{35}$. Thus, the selenocarbonyl compounds 1-11, shown in Table 1, have been examined in different biological studies at the ABCB1overexpressing Colo 320/MDR-LRP resistant cell line, as well as the equivalent sensitive cell line (Colo 205 doxorubicin sensitive cells), following previously described methodologies ${ }^{25,27,34-38}$. The selected derivatives 1-11 included the selenoanhydride 1 and the selenoesters 2-11, whose alkyl moiety contains different functional groups: a methyl group in $\mathbf{2 - 5}$, a methylcarbamoil group in 6, a methyloxycarbonylmethyl group in $\mathbf{7}$, a phenyloxycarbonylmethyl group in $\mathbf{8}$ and different ketonecontaining alkyl groups in 9-11. The selenocompounds 1-11 were synthesized according to the methods described earlier ${ }^{20,21}$.

The following biological evaluations were considered in this study: the assessment of their cytotoxicity, the inhibition of $\mathrm{ABCB} 1$ protein, and the ability of the compounds to induce apoptotic events. These biological activities were determined using rhodamine 123 accumulation assay, MTT method and flow cytometry measurements. Besides, the selectivity of the compounds towards cancer cells compared to normal cells was evaluated using the non tumoral MRC-5 human embryonic lung fibroblast cell line, as described previously ${ }^{39}$. The different selectivity indexes (SI) were calculated as the quotient of the $\mathrm{IC}_{50}$ value in the non-tumoral cells divided by the $\mathrm{IC}_{50}$ in the MDR cancer cell line. The compounds activity towards cancer cells is considered as strongly selective if the selectivity index (SI) value is higher than 6 , moderately selective if $3<\mathrm{SI}<6$, slightly selective if $1<\mathrm{SI}<3$ and non-selective if SI is lower than $1^{40}$. Previously reported studies ${ }^{41-43}$ have evaluated the selectivity of novel antiproliferative and cytotoxic agents towards colon/colorectal cancer cells using human ${ }^{41}$ or murine o $^{42-43}$ fibroblasts as non-tumoral cell lines. Among them, Meker et al. ${ }^{41}$ compared the antiproliferative activity of novel titanium complexes in HT-29 colon adenocarcinoma cells and in MRC-5 human non-tumoral lung fibroblasts. In addition, our group determined the selective action of different selenium compounds between CT-26 murine colon carcinoma cells and NIH-3T3 murine fibroblasts (data not published yet). Based on these lines of evidence, we have chosen the MRC-5 cell line to evaluate the selectivity of the selenocompounds 1-11 towards the colon adenocarcinoma cell lines Colo 205 and Colo 320.

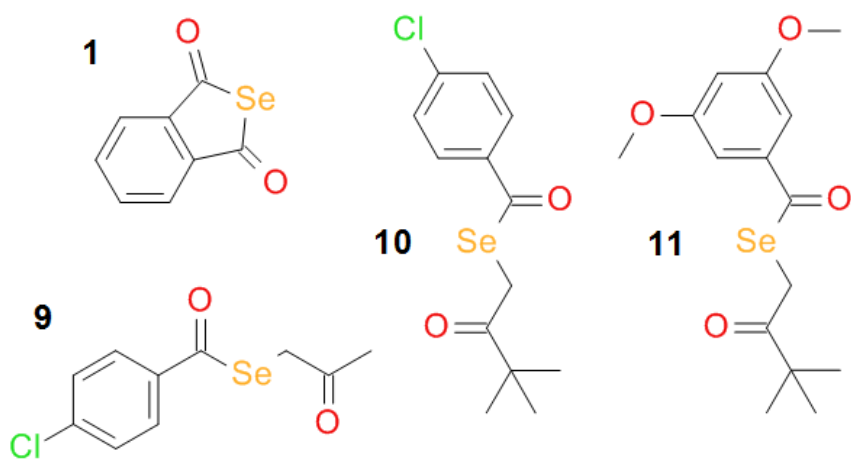

Figure 1. Chemical structure of the most active selenocompounds.

The rhodamine 123 accumulation assay ${ }^{25,34-37}$ was selected to determine the capacity of compounds 1-11 to inhibit the extrusion of the dye (an ABCB1 substrate) out of the MDR Colo 320 cancer cells. Verapamil was chosen as positive control. To determine the activity of these derivatives, the fluorescence 
intensity emitted by the treated cells was measured and the mean for the treated cells was calculated and compared with the untreated cells. Results were given in terms of the fluorescence activity ratio (FAR), as indicated in equation (1). Once the FAR values were determined, they are divided by the FAR of verapamil, as showed in equation (2), to calculate the FAR quotient. The values determined for the compounds evaluated are provided in Table 2.

Table 2. Fluorescence activity ratios calculated for selenocarbonyl compounds in rhodamine 123 retention assay using multidrug resistant human Colo 320/MDR-LRP colon adenocarcinoma cells.

\begin{tabular}{|c|c|c|c|}
\hline Sample & $\begin{array}{c}\text { Concentration } \\
(\mu \mathrm{M})\end{array}$ & FAR $^{1}$ & $\begin{array}{c}\text { FAR } \\
\text { Quotient } \\
(\%)^{2}\end{array}$ \\
\hline 1 & 2 & 3.86 & 135.4 \\
\hline 1 & 20 & 12.3 & 431.9 \\
\hline 2 & 2 & 0.64 & 22.46 \\
\hline 2 & 20 & 0.59 & 20.70 \\
\hline 3 & 2 & 0.55 & 19.30 \\
\hline 3 & 20 & 0.63 & 22.11 \\
\hline 4 & 2 & 0.53 & 18.60 \\
\hline 4 & 20 & 0.68 & 23.86 \\
\hline 5 & 2 & 0.55 & 19.30 \\
\hline 5 & 20 & 0.58 & 20.35 \\
\hline 6 & 2 & 0.60 & 21.05 \\
\hline 6 & 20 & 0.58 & 20.35 \\
\hline 7 & 2 & 0.79 & 27.72 \\
\hline 7 & 20 & 0.75 & 26.32 \\
\hline 8 & 2 & 0.75 & 26.32 \\
\hline 8 & 20 & 1.94 & 68.07 \\
\hline 9 & 2 & 11.4 & 401.1 \\
\hline 10 & 2 & 6.19 & 217.2 \\
\hline 11 & 2 & 6.49 & 227.7 \\
\hline 12 & 2 & 0.50 & 10.83 \\
\hline 12 & 20 & 0.73 & 15.70 \\
\hline 13 & 2 & 0.76 & 16.49 \\
\hline 13 & 20 & 0.70 & 15.09 \\
\hline 14 & 2 & 0.61 & 13.16 \\
\hline 14 & 20 & 0.41 & 8.93 \\
\hline 15 & 2 & 0.88 & 19.12 \\
\hline 15 & 20 & 0.61 & 13.14 \\
\hline Verapamil $^{3}$ & 20 & 2.85 & 100.0 \\
\hline Verapamil $^{4}$ & 20 & 4.63 & 100.0 \\
\hline DMSO$^{3}$ & $2 \mathrm{~V} / \mathrm{V} \%$ & 0.53 & 18.60 \\
\hline $\mathrm{DMSO}^{4}$ & $2 \mathrm{~V} / \mathrm{V} \%$ & 0.59 & 12.72 \\
\hline
\end{tabular}

${ }^{1}$ FAR: Fluorescence activity ratio, calculated as follows:

$$
F A R=\frac{M D R_{\text {treated }} / M D R_{\text {control }}}{\text { sensitive treated } / \text { sensitive control }}
$$

${ }^{2}$ Calculated as follows:

$$
\text { Quotient }=\frac{F A R_{\text {compound }}}{F A R_{\text {verapamil }}} \times 100
$$

${ }^{3}$ Values obtained during the assays for the series of compounds $\mathbf{1 - 1 1}$. FAR quotients of compounds 1-11 are calculated in respect to verapamil ${ }^{3}$

${ }^{4}$ Values obtained during the assays for the additional compounds 12-15. FAR quotients of compounds $\mathbf{1 2 - 1 5}$ are calculated in respect to verapamil ${ }^{4}$.
Additionally, Figure 2 compares the activity of the most potent inhibitors in colon adenocarcinoma cells with that in MDR-derived mouse T-lymphoma cell line ${ }^{25}$.

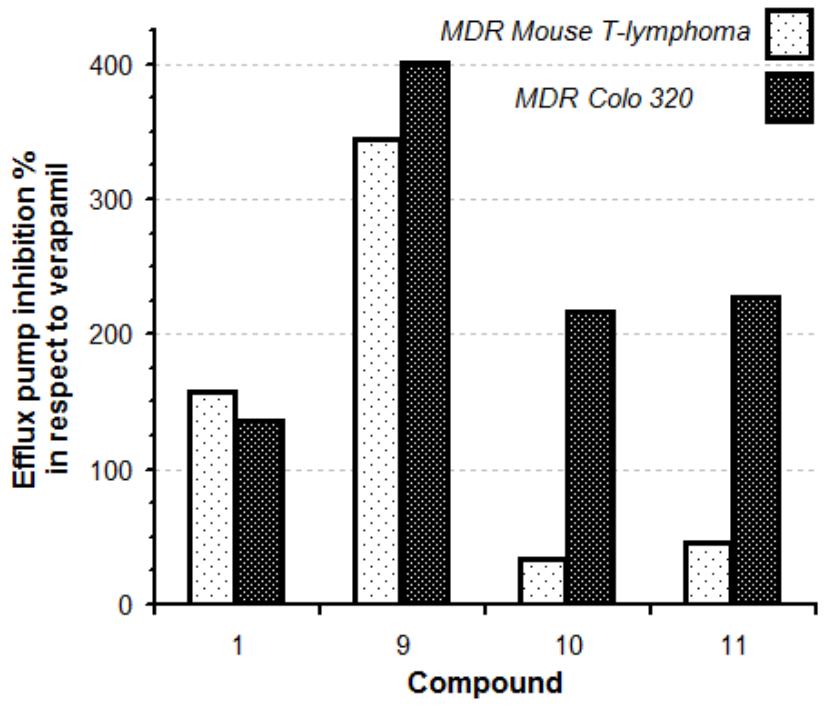

Figure 2. FAR quotient values, expressed in terms of percentages in respect to verapamil tested at 10-fold higher concentration (activity of verapamil $=100 \%$ ), calculated for the most active compounds $(\mathbf{1}, 9-11)$ in MDR mouse T-lymphoma cell line ${ }^{25}$ and in MDR Colo 320 cells.

According to the results obtained, the most active compounds (1 and 9-11) showed a strong efflux pump inhibition: (1.3-4.0)fold higher compared to verapamil at a concentration 10 times lower. The inhibiting activity of selenoanhydride 1 was 4.32 -fold stronger than that of verapamil when tested at the same $20 \mu \mathrm{M}$ concentration $\left(\mathbf{9 - 1 1}\right.$ were not tested at $20 \mu \mathrm{M}$ as they had $\mathrm{IC}_{50}$ values more than 10 times lower than this concentration). The $\mathrm{ABCB} 1$ inhibition measured at $2 \mu \mathrm{M}$ concentration for the active compounds ( $\mathbf{1}$ and 9-11) in MDR Colo 320 cells indicated a significant increase of the inhibiting activity of 9-11 in comparison to that described for the $A B C B 1$-transfected mouse T-lymphoma cells ${ }^{25}$. As shown in Figure 2, the highest improvement was found in the case of derivatives $\mathbf{1 0}$ and 11, where the inhibition compared to verapamil, raised from $34 \%$ to $217 \%$ and from $46 \%$ to $228 \%$, respectively. On the other hand, derivatives 2-7 exerted a low modulating action on the ABCB1 efflux pump, as their pump inhibitory action varied from $18 \%$ to $28 \%$ of the inhibitory action exerted by the reference verapamil. In addition the phenoxycarbonyl selenoester $\mathbf{8}$ showed a significant inhibition of the efflux pump (68.1\% of verapamil activity at the same concentration - $20 \mu \mathrm{M}$ ).

In accordance to the results obtained for MDR mouse Tlymphoma cells, these results show that the four derivatives with potent efflux pump inhibitory activity are the cyclic selenoanhydride 1, and the ketone selenoesters (9-11). The selenoesters with secondary non-ketone functional groups (ester, amide, or a methyl group) have a weaker MDR reversing activity, both in MDR colon adenocarcinoma and in MDR mouse T-lymphoma MDR cells. This fact suggests that the influence of the selenocarbonyl moiety (selenoanhydride, selenoester) and of the secondary carbonyl functional group present in the alkyl moiety bound to selenium in the selenoesters seems to be more relevant for the efflux pump inhibition than the different substituents at the aromatic moiety bound to the carbonyl group of the selenoesters evaluated. As proposed earlier ${ }^{20,25}$, the 
observed changes of the activity with the functional group can be explained both by the polarity modulation and by the modification of the selenoester hydrolysis exerted by the functional group present in the alkyl moiety bound to the selenium atom. These modifications in the substituents placed at the opposite side of the molecule may exert a minor influence over the selenoester, as these substituents are placed at a higher distance of the selenium atom than the functional groups of the alkyl moiety. Considering the data obtained at $2 \mu \mathrm{M}$ concentration for the efflux pump inhibition using rhodamine 123 retention assay in Colo 320 cells, the most active compound is the methylketone selenoester 9, with a 2-fold stronger efflux pump inhibitory activity than the two tert-butylketone selenoesters $\mathbf{1 0}$ and $\mathbf{1 1}$ and with a 3-fold stronger ABCB1 inhibiting effect than that of the selenoanhydride 1. Among the tert-butylketones, there were no significant differences in the activity when the 3,5-dimethoxyphenyl moiety of $\mathbf{1 1}$ was replaced by the 4-chlorophenyl one of 10. In MDR mouse Tlymphoma cells ${ }^{25}, \mathbf{9}$ is also the most active compound at $2 \mu \mathrm{M}$ with a 2-fold higher activity than $\mathbf{1}$, but in this case $\mathbf{1 0}$ and $\mathbf{1 1}$ showed a much lower inhibition activity (Figure 2).

Interestingly, the replacement of the $\mathrm{Se}$ atom of $\mathbf{1}$ with an oxygen atom (12) practically eliminated the capacity of $\mathbf{1}$ to inhibit the ABCB1 efflux pump. The FAR quotient of $\mathbf{1 2}$ was much lower than that of $\mathbf{1}$ at the two concentrations assayed, and even 27 -fold lower at the $20 \mu \mathrm{M}$ concentration. A lack of the efflux pump inhibitory properties can be observed for the three inorganic chalcogen cyanates $\mathbf{1 3 - 1 5}$, as well. All reference compounds (12-15) displayed a very weak ABCB-1 inhibition (FAR quotient <20), in the range of DMSO, incomparably lower than the active selenoesters 9-11. Although the comparison of results for $\mathbf{1}$ and $\mathbf{1 2}$ underlines a crucial and irreplaceable role of Selenium within the cyclic anhydrides, results for three cyanates 13-15 indicate that not only presence but a particular location and the type of bonding are responsible for the efflux pump inhibitory properties. Hence, the endocyclic position of Se in the vicinity of carbonyl groups seems to be very profitable whereas the $\mathrm{CN}$ neighborhood and significant alkaline properties are unfavorable regardless of the chalcogen atom (Se, $\mathrm{O}$ or $\mathrm{S}$ ). These results additionally confirmed the inference about the beneficial role of the ketone group within Se-compounds for the ABCB-1 inhibitory properties, coming from the studies on compounds 1 11 in both T-Lymphoma and Colo-cancer cells.

The cytotoxicity exerted by the selenocarbonyl compounds 1-11 in both the sensitive and resistant Colo cells was measured using MTT method, and results were given in terms of $\mathrm{IC}_{50}$ values (Table 3). The three most active derivatives (9-11) had $\mathrm{IC}_{50}$ values in nanomolar range in MDR Colo 320 cells. Compound 11 was the most potent one with an $\mathrm{IC}_{50}$ of $350 \mathrm{nM}$. In the sensitive cell line, these three compounds showed $\mathrm{IC}_{50}$ values in the range from 1.19 to $5.48 \mu \mathrm{M}$. None of the remaining derivatives 1-8 were cytotoxic in the sensitive Colo 205 cell line at concentrations lower than the selected threshold $(100 \mu \mathrm{M})$; and only 1 and 4 showed $\mathrm{IC}_{50}$ values below $100 \mu \mathrm{M}$ against MDR Colo 320 cells. At the sight of the results, the ABCB1 efflux pump inhibitory activity of the selenoanhydride $\mathbf{1}$ is truly interesting for possible future applications in medicine: $\mathbf{1}$ exerts a 1.35-fold and a 4.32-fold stronger pump inhibition than verapamil at concentrations 32 times and 3.2 times lower, respectively, than the $\mathrm{IC}_{50}$ value determined for $\mathbf{1}$ in this resistant cell line. Interestingly, all the derivatives were more cytotoxic against the resistant Colo 320/MDR cell line than against the sensitive Colo 205 cells. The ketone selenoester 9 was the most selective compound against the MDR cell line, with a selectivity index (SI) of 10 to the MDR cells in respect to the sensitive cells.
Table 3. Cytotoxicity of selenocompounds on sensitive Colo 205 human colon adenocarcinoma cells, on the resistant Colo 320/MDR cell line, and on non-tumoral MRC-5 human embryonic lung fibroblasts. Selectivity of the compounds for colon adenocarcinoma cell lines in respect to MRC-5 non-tumoral cells.

\begin{tabular}{|c|c|c|c|c|c|c|c|c|c|}
\hline \multirow{2}{*}{ Cpd } & \multicolumn{2}{|c|}{$\begin{array}{c}\text { A - Colo } \\
205\end{array}$} & \multicolumn{2}{|c|}{ B - Colo 320} & \multirow{2}{*}{$\begin{array}{c}\text { SI } \\
\text { A/B }\end{array}$} & \multicolumn{2}{|c|}{ C - MRC-5 } & \multirow{2}{*}{$\begin{array}{c}\text { SI } \\
\text { C/A }\end{array}$} & \multirow{2}{*}{$\begin{array}{c}\text { SI } \\
\text { C/B }\end{array}$} \\
\hline & $\begin{array}{r}\mathrm{IC}_{50} \\
(\mu \mathrm{M})\end{array}$ & $\mathrm{SD} \pm$ & $\begin{array}{r}\mathrm{IC}_{50} \\
(\mu \mathrm{M}) \\
\end{array}$ & SD \pm & & $\begin{array}{l}I_{C_{50}} \\
(\mu \mathrm{M}) \\
\end{array}$ & SD \pm & & \\
\hline 1 & $>100$ & - & 63.9 & 2.12 & $\geq 1.6$ & $>100$ & - & - & $\geq 1.6$ \\
\hline 2 & $>100$ & - & $>100$ & - & - & 4.26 & 0.65 & $\leq 0.04$ & $\leq 0.04$ \\
\hline 3 & $>100$ & - & $>100$ & - & - & 17.9 & 0.00 & $\leq 0.18$ & $\leq 0.18$ \\
\hline 4 & $>100$ & - & 12.5 & 1.76 & $\geq 8.0$ & 28.4 & 0.70 & $\leq 0.28$ & 2.3 \\
\hline 5 & $>100$ & - & $>100$ & - & - & 61.5 & 2.16 & $\leq 0.62$ & $\leq 0.62$ \\
\hline 6 & $>100$ & - & $>100$ & - & - & 76.6 & 0.92 & $\leq 0.77$ & $\leq 0.77$ \\
\hline 7 & $>100$ & - & $>100$ & - & - & 33.4 & 3.08 & $\leq 0.33$ & $\leq 0.33$ \\
\hline 8 & $>100$ & - & 53.7 & 0.91 & $\geq 1.9$ & $>100$ & - & - & $\geq 1.9$ \\
\hline 9 & 5.48 & 0.75 & 0.55 & 0.11 & 10.0 & 5.35 & 0.24 & 0.98 & 9.7 \\
\hline 10 & 1.63 & 0.55 & 0.96 & 0.15 & 1.7 & 8.10 & 0.90 & 5.0 & 8.4 \\
\hline 11 & 1.19 & 0.21 & 0.35 & 0.09 & 3.4 & 5.04 & 0.71 & 4.2 & 14.4 \\
\hline 12 & $>100$ & - & $>100$ & - & - & $>100$ & - & - & - \\
\hline 13 & $>100$ & - & $>100$ & - & - & $>100$ & - & - & - \\
\hline 14 & $>100$ & - & $>100$ & - & - & $>100$ & - & - & - \\
\hline 15 & $>100$ & - & $>100$ & - & - & $>100$ & - & - & - \\
\hline
\end{tabular}

Cpd: compound, SI: Selectivity Index.

With the exception of derivatives $\mathbf{1}$ and $\mathbf{8}$, all compounds showed $\mathrm{IC}_{50}$ values below $100 \mu \mathrm{M}$ in the non-tumoral human MRC-5 lung fibroblast cell line. Among them, the $\mathrm{IC}_{50}$ values of compounds 3 , and 5-7 were from 17 to $77 \mu \mathrm{M}$, whereas the $\mathrm{IC}_{50}$ values of derivatives 2 and 9-11 placed in the $4-8 \mu \mathrm{M}$ range. It is noteworthy that the five most potent ABCB1 efflux pump inhibitors $(\mathbf{1}, \mathbf{8 - 1 1})$ exert a selective action towards the colon adenocarcinoma cells compared to the MRC- 5 cells, especially against the MDR cell line: $\mathbf{1}$ and $\mathbf{8}$ were slightly selective towards Colo 320 cells, and $\mathbf{9 - 1 1}$ showed a strong selectivity towards the resistant cells (the most selective, $\mathbf{1 1}$, had a SI =14.4). Among them, $\mathbf{1 0}$ and $\mathbf{1 1}$ were moderately selective towards the sensitive Colo 205 cell line. In contrast, the remaining selenocompounds (2-7) were non-selective, with the exception of $\mathbf{4}$ on Colo 320 MDR cells $(\mathrm{SI}=2.3$, slightly selective). None of the four reference compounds evaluated (12-15) showed cytotoxic activity in any of the cell lines assayed: the human colon adenocarcinoma cells (Colo 205 and Colo 320, Table 3), the non-tumoral MRC-5 cells (Table 3) and the mouse T-lymphoma cells (PAR and MDR, data now shown). In the case of the pair selenoanhydride (1) - phthalic anhydride (12), results highlight the importance of the selenium atom to the biological activity.

Regarding the SAR in the cytotoxicity assay, only the ketone selenoesters 9-11 showed $\mathrm{IC}_{50}$ values below $10 \mu \mathrm{M}$ in both colon adenocarcinoma cell lines. The tert-butylketone selenoesters were more cytotoxic than the methylketone one in sensitive Colo 205 cells. In the resistant Colo 320 cells, with the equivalent aromatic substituent (4-chlorophenyl), the methyl ketone selenoester 9 was 2-fold more cytotoxic than the tert-butylketone 10. In addition, the change of the aromatic moiety from the 4chlorophenyl (10) to the 3,5-dimethoxyphenyl (11) moiety improved the cytotoxicity and converted $\mathbf{1 1}$ into the most cytotoxic selenocompound. In contrast, the selenoanhydride $\mathbf{1}$ was not cytotoxic at concentrations below $100 \mu \mathrm{M}$ in sensitive cells, and was less active $(63.9 \mu \mathrm{M})$ than $\mathbf{9 - 1 1}$ in resistant cells. 
The SAR analysis for the selectivity towards the cancer cells compared to MRC-5 non-tumour cell line is in analogy with that one observed for the cytotoxicity in resistant Colo 320 cells. In this case, $\mathbf{1 1}$ is the most selective compound.

Table 4. Capacity of the selenocompounds evaluated to induce different apoptotic events in MDR Colo 320 cells after 3 hours of incubation, measured by flow cytometry.

\begin{tabular}{|c|c|c|c|c|c|c|}
\hline & \multirow[b]{2}{*}{$\begin{array}{l}\text { Conc } \\
(\mu \mathrm{M})\end{array}$} & \multicolumn{5}{|c|}{ Gated events in MDR Colo 320 cells } \\
\hline & & $\begin{array}{c}\text { Early } \\
\text { aps \%) }\end{array}$ & $\begin{array}{c}\text { Late aps } \\
\text { necrosis } \\
(\%)\end{array}$ & $\begin{array}{c}\text { Cell } \\
\text { death } \\
(\%)\end{array}$ & $\begin{array}{c}\text { Total } \\
\text { apt } \\
\text { events } \\
(\%) \\
\end{array}$ & $\begin{array}{c}\text { Apt } \\
\text { quot. } \\
(\%)\end{array}$ \\
\hline A- I- & - & 3.42 & 0.00 & 0.46 & 3.42 & 4.25 \\
\hline A- I+ & - & 2.33 & 0.10 & 14.0 & 2.43 & 3.02 \\
\hline A+ I- & - & 23.6 & 0.00 & 0.00 & 23.6 & 29.3 \\
\hline $\mathbf{A}+\mathbf{I}+$ & - & 13.5 & 5.58 & 10.5 & 19.1 & 23.7 \\
\hline DMSO & $2 \%$ & 20.3 & 9.93 & 4.75 & 30.2 & 37.6 \\
\hline M627 & 20 & 58.5 & 22.0 & 2.91 & 80.5 & 100 \\
\hline 1 & 2 & 66.1 & 5.08 & 1.41 & 71.2 & 88.4 \\
\hline 2 & 2 & 12.0 & 12.5 & 7.56 & 24.5 & 30.4 \\
\hline 3 & 2 & 16.3 & 13.4 & 5.69 & 29.7 & 36.9 \\
\hline 4 & 2 & 13.4 & 15.8 & 6.37 & 29.2 & 36.3 \\
\hline 5 & 2 & 16.2 & 13.5 & 4.93 & 29.7 & 36.9 \\
\hline 6 & 2 & 14.3 & 15.7 & 4.98 & 30.0 & 37.3 \\
\hline 7 & 2 & 20.5 & 14.4 & 5.55 & 34.9 & 43.4 \\
\hline 8 & 2 & 16.0 & 18.6 & 10.4 & 34.6 & 43.0 \\
\hline 9 & 2 & 28.9 & 41.7 & 15.3 & 70.6 & 87.7 \\
\hline 10 & 2 & 28.8 & 35.8 & 15.4 & 64.6 & 80.3 \\
\hline 11 & 2 & 29.7 & 41.7 & 11.6 & 71.4 & 88.7 \\
\hline 12 & 2 & 3.79 & 1.09 & 7.18 & 4.88 & 6.06 \\
\hline 13 & 2 & 4.11 & 1.75 & 7.28 & 5.86 & 7.28 \\
\hline 14 & 2 & 6.07 & 1.62 & 6.98 & 7.69 & 9.55 \\
\hline 15 & 2 & 4.22 & 1.40 & 7.39 & 5.62 & 6.98 \\
\hline
\end{tabular}

A+: Annexin V-FITC staining, A-: without Annexin V-FITC, I+: propidium iodide staining, I-: without propidium iodide; Conc: concentration; aps: apoptosis; apt: apoptotic; M627: 12H-benzo[ $\alpha]$ phenothiazine. 'Total apoptotic events' is the sum of 'early apoptosis' and 'late apoptosis, necrosis'. 'Apoptotic quotient' is the sum of apoptotic events of the compound divided by the sum of apoptotic events caused by M627.

The ability of the compounds to trigger the different apoptotic processes in resistant Colo 320 cells was determined using flow cytometry. Selenocompounds 1-11 were evaluated at a $2 \mu \mathrm{M}$ concentration, and the apoptotic derivative M627 (12Hbenzo $[\alpha]$ phenothiazine $)^{38}$ was tested as positive control at a $20 \mu \mathrm{M}$ concentration. Results are provided in Table 4 and the pro-apoptotic activity of the most active derivatives $(\mathbf{1}, \mathbf{9 - 1 1})$ in MDR-derived mouse T-lymphoma cells ${ }^{25}$ and in the resistant Colo 320 human cell line are compared in Figure 3. Like in MDR mouse T-lymphoma cells ${ }^{25}$, the selenoanhydride $\mathbf{1}$ and the ketone selenoesters 9-11 showed a strong capacity to trigger apoptotic events in resistant colon adenocarcinoma cells. These active derivatives induced apoptosis (including early and late apoptosis, and necrosis) in 64-72\% of the gated cells, almost in the same range than the positive control $(80.5 \%)$ but at a 10 -fold lower concentration, reaching in this way an $80-90 \%$ of the action of the positive control M627 at a 10-fold lower concentration. As shown in Figure 3, derivatives $\mathbf{1 0}$ and $\mathbf{1 1}$ were clearly stronger apoptosis inducers in colon cells than in Tlymphoma cells, whereas the M627, 1 and 9 were slightly more pro-apoptotic in mouse MDR T-lymphoma cell line. The remaining selenoesters $\mathbf{2 - 8}$ were moderate apoptosis inducers, as they triggered apoptotic events in $24-35 \%$ of cells at a 10 -fold lower concentration than that of the positive control. Among these derivatives, only the selenoesters $\mathbf{7 - 8}$ could induce apoptotic events in more than one third of the gated cells. Both contain a carboxylic ester in the alkyl moiety bound to the selenium atom. Finally, the four references $\mathbf{1 2 - 1 5}$ had no capacity to induce apoptotic events in Colo 320 cells as they have apoptotic quotients close to negative controls, and as all the selenocompounds 1-11 induce apoptotic events in a significantly higher percentage than the reference compounds 12-15.

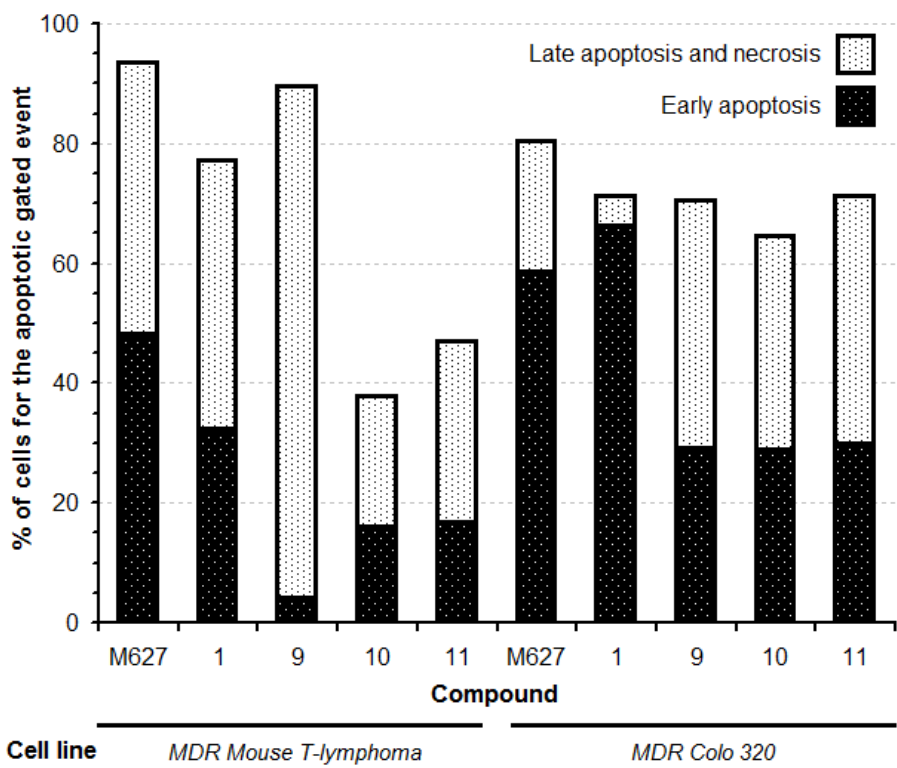

Figure 3. Percentage of cells which undergone apoptotic events (early apoptosis and late apoptosis/necrosis) after exposure to the compounds 1-11 or to M627 (positive control), in MDR-derived mouse T-lymphoma cell line ${ }^{25}$ (left) and in MDR human Colo 320 adenocarcinoma cells (right).

In the SAR analysis of the apoptosis induction assays, it is noteworthy that the selenoanhydride $\mathbf{1}$ and the active ketone selenoesters 9-11 exerted differential apoptotic actions: in the case of the selenoanhydride 1 the early apoptotic processes were triggered in the $66.1 \%$ of cells and weakly the late apoptotic/necrotic events ( $5.1 \%$ of cells). On the other hand, the ketone derivatives 9-11 were more potent inducers of late apoptosis and necrotic processes (35-42\% of cells) than of early apoptosis (28-30\% of cells). Both the selenoanhydride $\mathbf{1}$ and the ketone selenoesters 9-11 were stronger inducers of the early apoptosis and of the late apoptosis/necrosis, respectively, than the positive control M627. Among the ketone selenoesters, the methylketone selenoester 9 was more pro-apoptotic than the tertbutylketone selenoester (10) with the same aromatic substituent. But replacing the 4-chlorophenyl substituent of $\mathbf{1 0}$ with the 3,5dimethoxyphenyl moiety of $\mathbf{1 1}$ augments the apoptotic potency to convert the compound $\mathbf{1 1}$ into the most pro-apoptotic one.

To conclude, this study in human colonic adenocarcinoma cell lines confirms the results previously obtained in MDR mouse Tlymphoma cells ${ }^{25}$. Among the 11 selenocompounds evaluated, the selenoanhydride 1 and the ketone selenoesters 9-11 have showed a very interesting activity in the different biological assays performed. According to the results presented herein, these four active derivatives are more potent inhibitors of the ABCB1 efflux pump than the reference verapamil and also excellent apoptosis inducers. In addition, the three ketone selenoesters 9-11 are potent and strongly selective cytotoxic 
agents, as they showed $\mathrm{IC}_{50}$ values in nanomolar range at the resistant Colo 320 cells whereas their $\mathrm{IC}_{50}$ increased to the micromolar range in the non-tumour MRC-5 cell line. In addition, the replacement of the selenium atom of the selenoanhydride 1 by oxygen (12) eliminates the aforesaid interesting activities shown by $\mathbf{1}$. In the case of the inorganic chalcogen compounds 13-15, none of them showed activity regarding the efflux pump inhibition, cytotoxicity or apoptosis induction. The results for selenoanhydride 1 and selenoesters 211 together with those for the additional compounds 12-15 underline a beneficial role of both Se- and ketone moiety, whereas a presence of ester, amide or cyanate moieties as well as an absence of selenium result in total decrease of the desirable biological actions. These results in a second pair of sensitive/multidrug resistant cancer cell lines promote this series of selenocompounds $(\mathbf{1}, \mathbf{9 - 1 1})$ as promising agents to overcome cancer multidrug resistance, giving a new therapeutic perspective.

\section{Acknowledgments}

The authors are grateful to Mrs. Anikó Váradi Vigyikán for laboratory work and assistance; and to Prof. Dr. Juan Antonio Palop for his contribution and guidance in the design and structural characterization of the derivatives. This study was supported by the Szeged Foundation for Cancer Research, the European Union and the State of Hungary, co-financed by the European Social Fund in the framework of TÁMOP 4.2.4. A/211-1-2012-0001 'National Excellence Program'. This paper was also supported by the János Bolyai Research Scholarship of the Hungarian Academy of Sciences.

\section{Supplementary data}

The material and methods descriptions of the experiments described in this study can be found in the supplementary data associated to the article, in the online version, at ...

\section{References and notes}

1. Sanmartín C, Plano D, Sharma AK, Palop JA. Int J. Mol. Sci. 2012;13:9649-9672.

2. Fernandes AP, Gandin V. Biochim Biophys Acta. 2015;1850:1642-1660.

3. Rayman MP. Lancet. 2012;379:1256-1268

4. Weekley CM, Jeong G, Tierney ME, Hossain F, Maw AM, Shanu A, Harris HH, Witting PK. J Biol Inorg Chem. 2014;19:813-828.

5. Estevam EC, Witek K, Faulstich L, Nasim MJ, Latacz G, Domínguez-Álvarez E, Kieć-Kononowicz K, Demasi M, Handzlik J, Jacob C. Molecules. 2015;20:13894-13912.

6. Abdel-Aziz AK, Azab SS, Youssef SS, El-Sayed AM, ElDemerdash E, Shouman S. Basic Clin Pharmacol Toxicol. 2015; 116:37-46.

7. Sakalli Çetin E, Nazıroğlu M, Çiğ B, Övey İS, Aslan Koşar P. J Recept Signal Transduct Res. 2017;37:84-93.

8. Peyroche G, Saveanu C, Dauplais M, Lazard M, Beuneu F, Decourty L, Malabat C, Jacquier A, Blanquet S, Plateau P. PLoS One. 2012:7:e36343.

9. Wadhwani SA, Shedbalkar UU, Singh R, Chopade BA. Appl Microbiol Biotechnol. 2016;100:2555-2566.

10. Wang Y, Chen P, Zhao G, Sun K, Li D, Wan X, Zhang J. Food Chem Toxicol. 2015;85:71-77.

11. Estevam EC, Griffin S, Nasim MJ, Denezhkin P, Schneider R, Lilischkis R, Domínguez-Álvarez E, Witek K, Latacz G, Keck C, Schäfer KH, Kieć-Kononowicz K, Handzlik J, Jacob C. J Hazard Mater. 2017;324:22-30.

12. Guo CH, Hsia S, Shih MY, Hsieh FC, Chen PC. Int J Med Sci. 2015;12:748-758.

13. Li W, Guo M, Liu Y, Mu W, Deng G, Li C, Qiu C. Biol Trace Elem Res. 2016;171:371-379.
14. Qi Y, Fu X, Xiong Z, Zhang H, Hill SM, Rowan BG, Dong Y. PLoS One. 2012;7:e31539.

15. Chakraborty P, Roy SS, Bhattacharya S. Anticancer Agents Med Chem. 2015;15:501-510.

16. Roy SS, Chakraborty P, Biswas J, Bhattacharya S. Biochimie. 2014;105:137-148.

17. Alcolea V, Plano D, Encío I, Palop JA, Sharma AK, Sanmartín C. Eur J Med Chem. 2016;123:407-418.

18. Hussain RA, Badshah A, Pezzuto JM, Ahmed N, Kondratyuk TP, Park EJ. J Photochem Photobiol B. 2015;148:197-208.

19. Alcolea V, Plano D, Karelia DN, Palop JA, Amin S, Sanmartín C, Sharma AK. Eur J Med Chem. 2016;113:134-144.

20. Domínguez-Álvarez E, Plano D, Font M, Calvo A, Prior C, Jacob C, Palop JA, Sanmartín C. Eur J Med Chem. 2014;73:153-166.

21. Sanmartín C, Plano D, Dominguez E, Font M, Calvo A, Prior C, Encío I, Palop JA. Molecules. 2009;14:3313-3338.

22. Jamier V, Ba LA, Jacob C. Chemistry. 2010;16:10920-10928.

23. Mániková D, Letavayová LM, Vlasáková D, Košík P, Estevam EC, Nasim MJ, Gruhlke M, Slusarenko A, Burkholz T, Jacob C, Chovanec M. Molecules. 2014:19:12258-12279.

24. Fu X, Yang Y, Li X, Lai H, Huang Y, He L, Zheng W, Chen T. Nanomedicine. 2016;12:1627-1639.

25. Domínguez-Álvarez E, Gajdács M, Spengler G, Palop JA, Marć MA, Kieć-Kononowicz K, Amaral L, Molnár J, Jacob C, Handzlik J, Sanmartín C. Bioorg Med Chem Lett. 2016;26:2821-2824.

26. Brozmanová J, Mániková D, Vlčková V, Chovanec M. Arch Toxicol. 2010;84:919-938.

27. Spengler G, Handzlik J, Ocsovszki I, Viveiros M, KiecKononowicz K, Molnar J, Amaral L. Anticancer Res. 2011;31:3285-3288.

28. Wong K, Ma J, Rothnie A, Biggin PC, Kerr ID. Trends Biochem Sci. 2014;39:8-16.

29. Kathawala RJ, Gupta P, Ashby CR Jr, Chen Z. Drug Resist Updat. 2015;18:1-17.

30. Stavrovskaya AA, Stromskaya TP. Biochemistry (Moscow). 2008:73:592-604.

31. Fan C, Zheng W, Fu X, Li X, Wong YS, Chen T. Cell Death Dis. 2014;5:e1191.

32. Fan C, Zheng W, Fu X, Li X, Wong YS, Chen T. Oncotarget. 2014;5:2853-2863.

33. Cao S, Durrani FA, Tóth K, Rustum YM. Br J Cancer. 2014;110:1733-1743.

34. Takács D, Csonka Á, Horváth Á, Windt T, Gajdács M, Riedl Z, Hajós G, Amaral L, Molnár J, Spengler G. Anticancer Res. 2015;35:3245-3251.

35. Cornwell MM, Pastan I, Gottesman MM. J Biol Chem. 1987;262:2166-2170.

36. Spengler G, Viveiros M, Martins M, Rodrigues L, Martins A, Molnar J, Couto I, Amaral L. Anticancer Res. 2009;29:2173-2177.

37. Spengler G, Evaristo M, Handzlik J, Serly J, Molnár J, Viveiros M, Kieć-Kononowicz K, Amaral L. Anticancer Res. 2010;30:4867-4871.

38. Mucsi I, Varga A, Kawase M, Motohashi N, Molnar J. Anticancer Res. 2002;22:2833-2836.

39. Csupor-Löffler B, Hajdú Z, Zupkó I, Molnár J, Forgo P, Vasas A, Kele Z, Hohmann J. Planta Med. 2011;77:1183-1188.

40. Acton EM, Narayanan VL, Risbood PA, Shoemaker RH, Vistica DT, Boyd MR. J Med Chem. 1994;37:2185-2189.

41. Meker S, Braitbard O, Margulis-Goshen K, Magdassi S, Hochman J, Tshuva EY. Molecules. 2015;20:18526-18538.

42. Vieira AA, Brandão IR, Valença WO, de Simone CA, Cavalcanti BC, Pessoa C, Carneiro TR, Braga AL, da Silva EN. Eur J Med Chem. 2015;101:254-265.

43. Laurent A, Nicco C, Chéreau C, Goulvestre C, Alexandre J, Alves A, Lévy E, Goldwasser F, Panis Y, Soubrane O, Weill B, Batteux F. Cancer Res. 2005;65:948-956. 

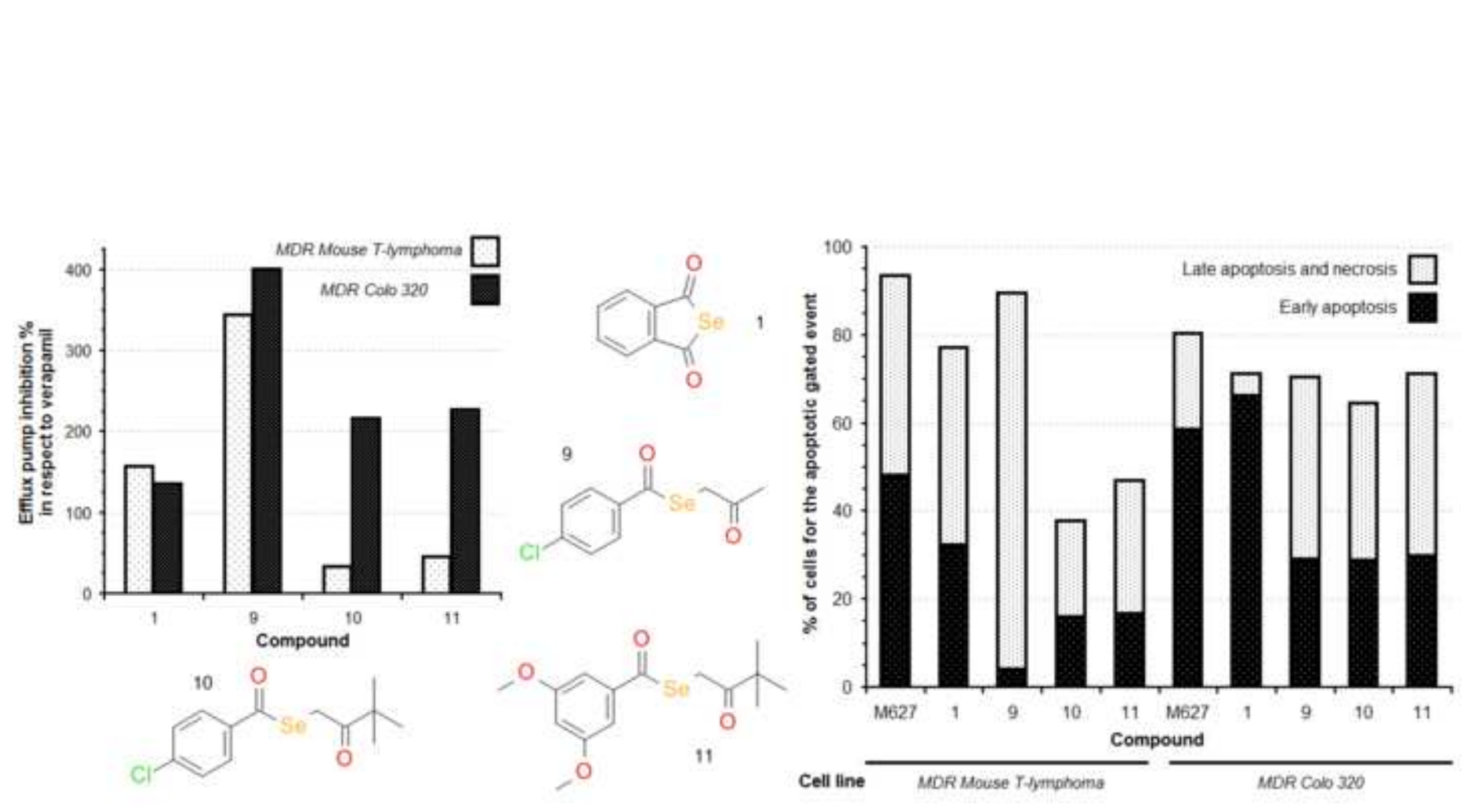

Graphical Abstract Figur 
Group A

Selenoanhydride

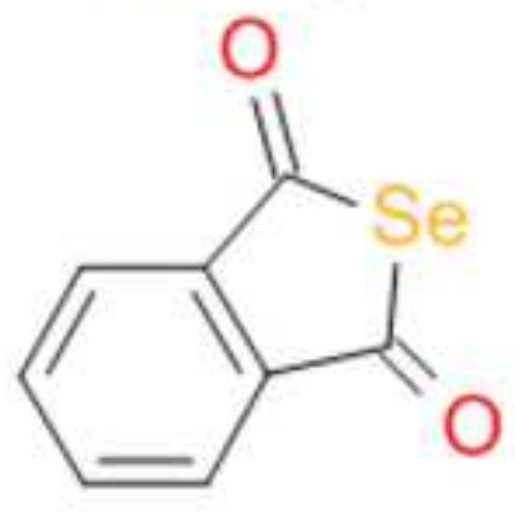

1
Group B

Selenoesters

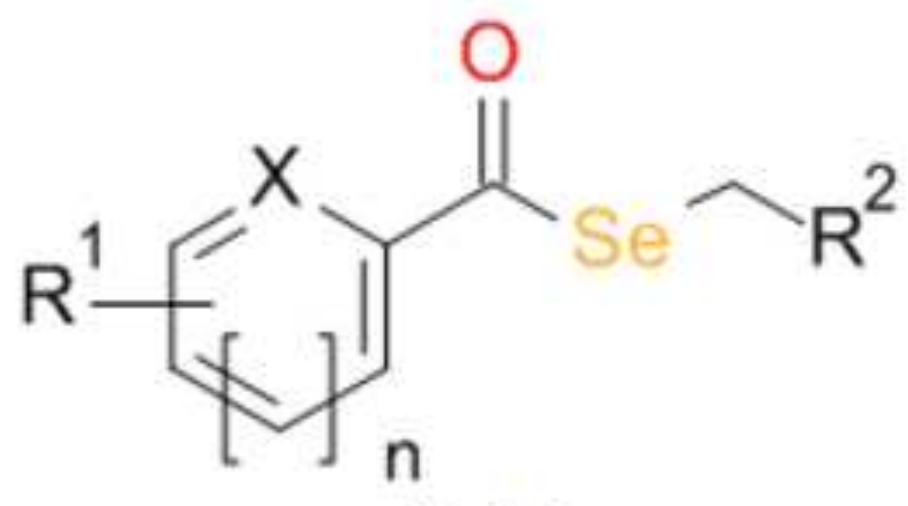

2-11

\section{Reference compounds}

Phthalic anhydride

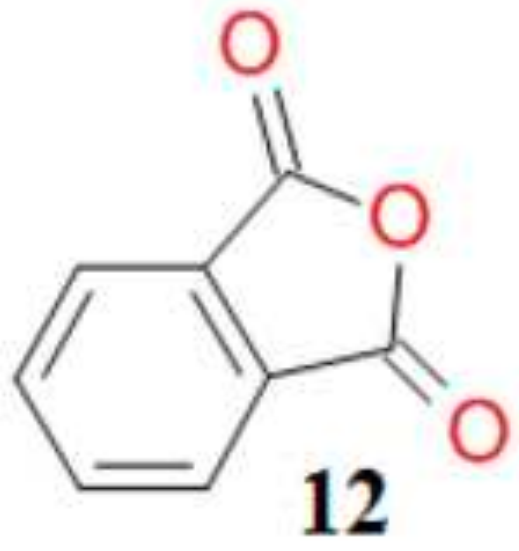

Chalcogen cyanates

13 - $\mathrm{KOCN}$

$14-\mathrm{NH}_{4} \mathrm{SCN}$

$15-\mathrm{KSeCN}$ 
Figure 1 Structures
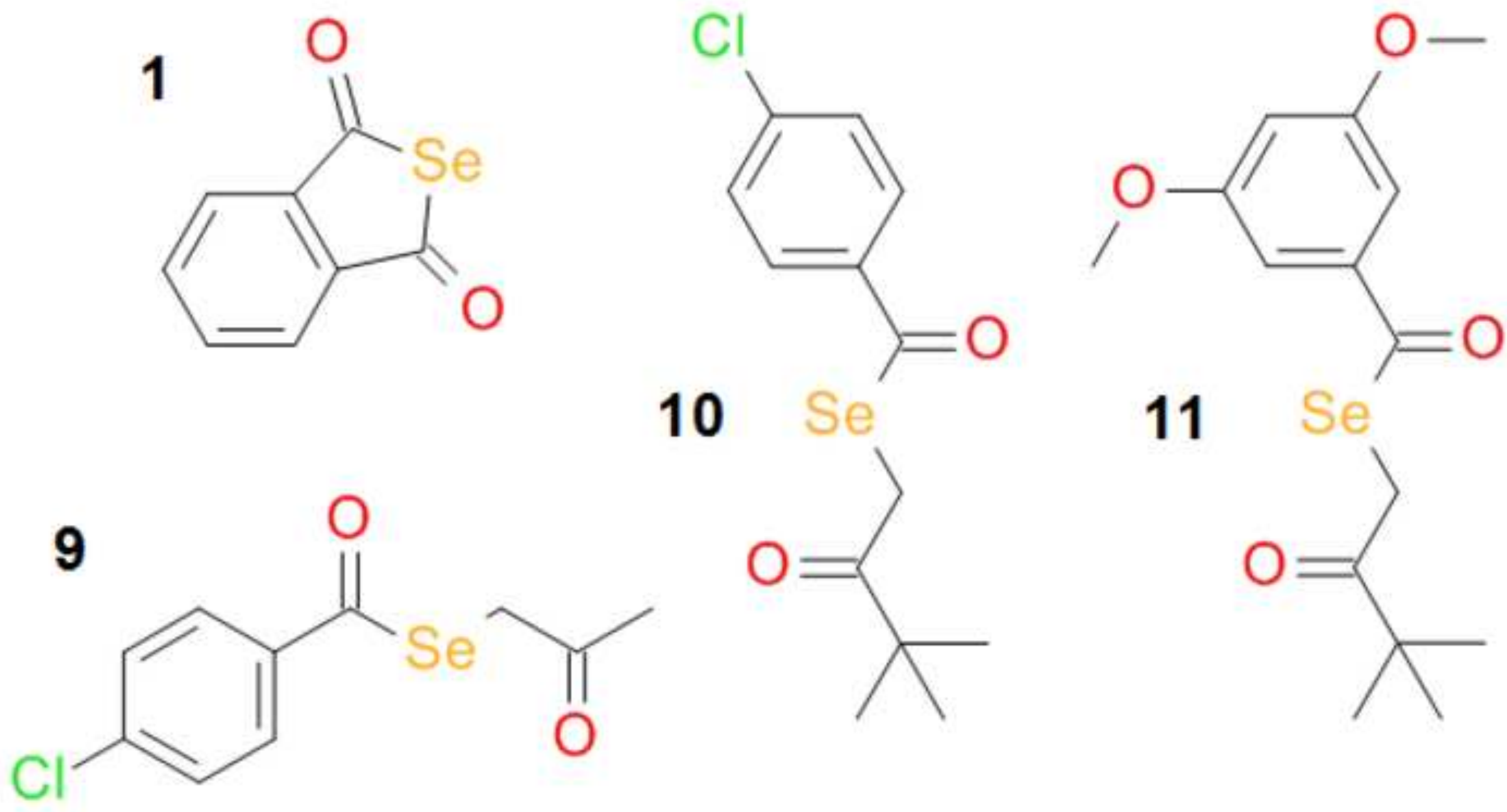

11
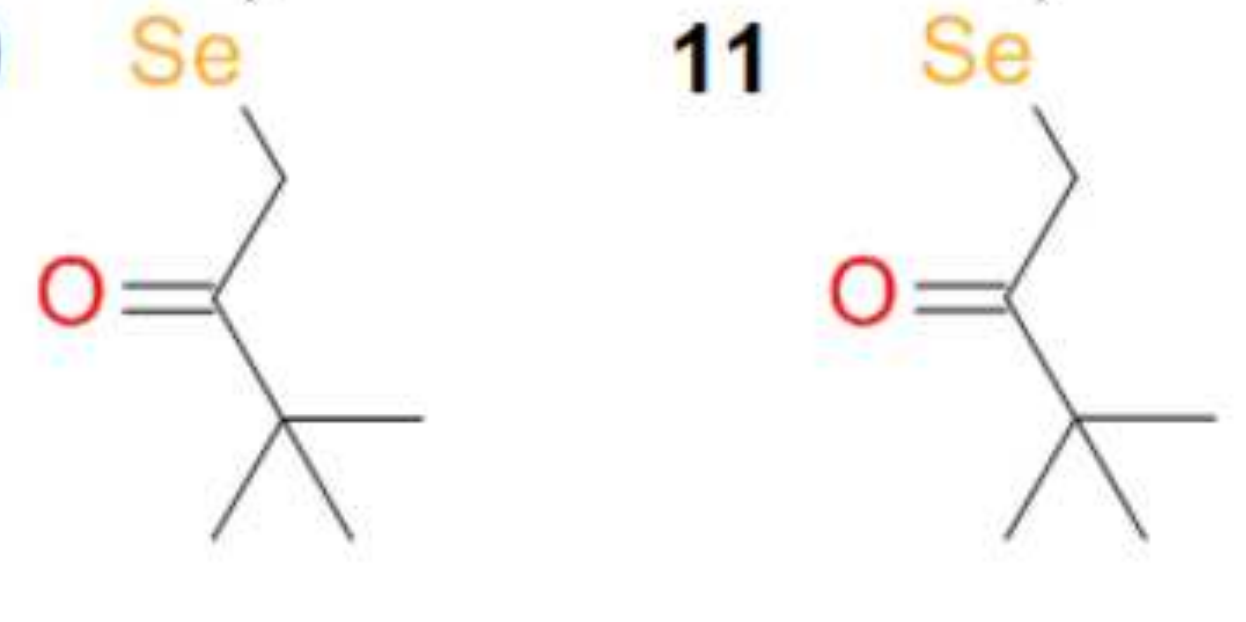


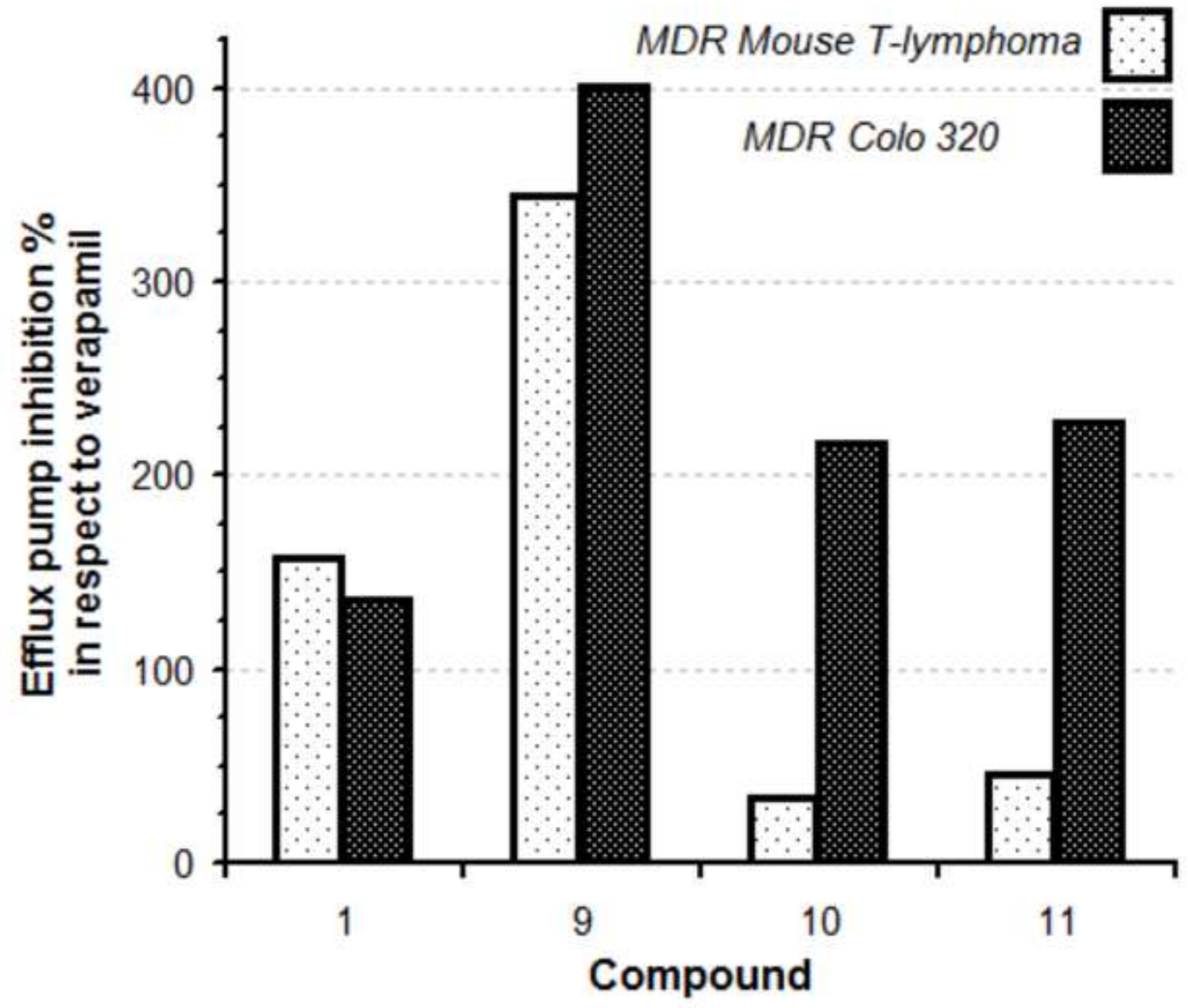




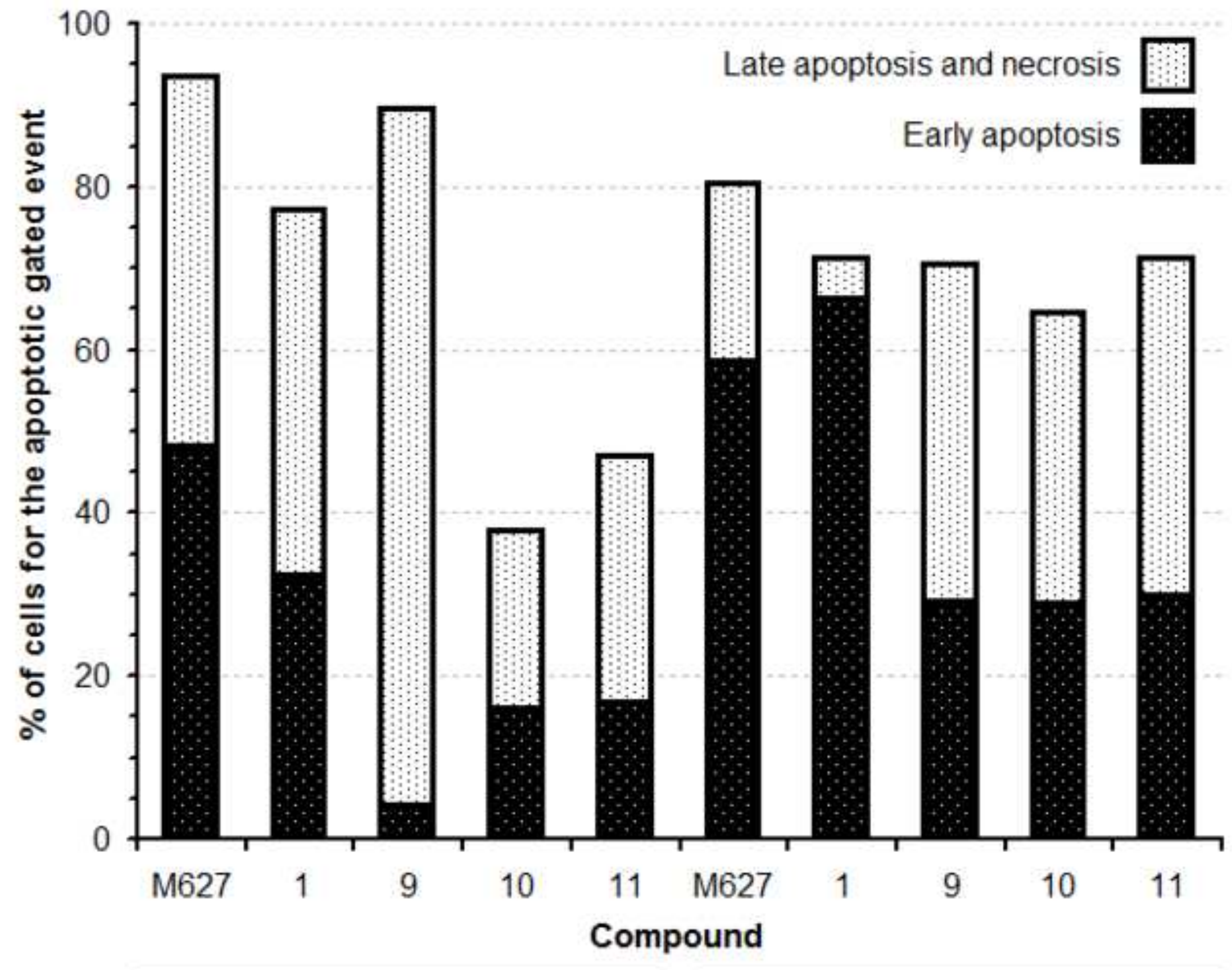

Cell line 

Supplementary Material Colo MDR 2nd Submission
Click here to download Supplementary Material: Sup

Click here to download Supplementary Material: Supplementary material Colo MDR 2nd Submission.doc 
Selenocompound 1 - Colo MDR manuscript
Click here to download Mol Files: Selenocompound 1 - Colo manuscript.mol

Selenocompound 1 - Colo MDR manuscript
Click here to download Mol Files: Selenocompound 1 - Colo manuscript.mol

Selenocompound 1 - Colo MDR manuscript
Click here to download Mol Files: Selenocompound 1 - Colo manuscript.mol

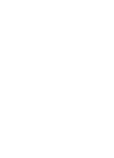

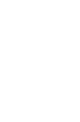

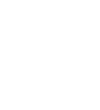

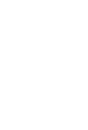
列 . 
Selenocompound 9 - Colo MDR manuscript
Click here to download Mol Files: Selenocompound 9 - Colo manuscript.mol

Selenocompound 9 - Colo MDR manuscript
Click here to download Mol Files: Selenocompound 9 - Colo manuscript.mol

Selenocompound 9 - Colo MDR manuscript
Click here to download Mol Files: Selenocompound 9 - Colo manuscript.mol

.

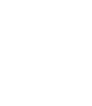

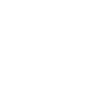

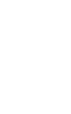

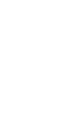
(1)

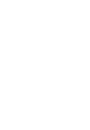
. . . . .

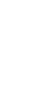

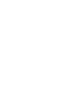

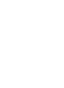

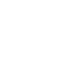

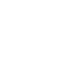

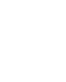

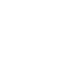

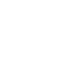

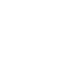

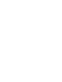

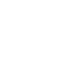

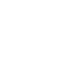
. 
Selenocompound 10 - Colo MDR manuscript
Click here to download Mol Files: Selenocom

Click here to download Mol Files: Selenocompound 10 - Colo manuscript.mol 
Selenocompound 11 - Colo MDR manuscript
Click here to download Mol Files: Selenocom

Click here to download Mol Files: Selenocompound 11 - Colo manuscript.mol 